\title{
MENINGKATKAN KEMAMPUAN ANALITIK DAN AKTIVITAS SISWA SMP MELALUI PENERAPAN MODEL PEMBELAJARAN POE (PREDICTION, OBSERVATION, EXPLANATION)
}

\author{
${ }^{1)}$ Anis Prasetiyaningsih \\ 1) SMP Negeri 3 Jember \\ Email: anisprasetiyaollien@gmail.com
}

\begin{abstract}
The research about the implementation of POE (Prediction, Observation, Explanation) learning model to improve the student's analytical thinking ability and student's activities in the learning process. This research used Classroom Action Research (CAR). It consist of two cycles. The object of research was 32 students of VIII F SMPN 3 Jember in Academic Year 2019/2020. The research instruments are observation sheets, test of student's analytical thinking ability. The result of the study showed that the use of learning model POE improve from cycle I to cycle II include (1) the student's analytical thinking $73 \%$ in cycle I to $88 \%$ in cycle II (2) there was the improvement of student's activities $74.5 \%$ (Good) in cycle I to $82,4 \%$ (Very Good) in cycle II.
\end{abstract}

Keywords: analytical thinking ability, student's activities, POE Learning Model.

\section{PENDAHULUAN}

Tujuan pembelajaran IPA di sekolah adalah memberikan pengetahuan guna memahami konsep IPA dan keterkaitannya. Kemampuan siswa dalam menerapkan metode ilmiah untuk memecahkan masalah dalam kehidupan sehari-hari sebagai sebuah keterampilan poses sains perlu dibekalkan. Pembelajaran harus dapat memberi kesempatan luas kepada siswa untuk dapat melakukan hands-on maupun minds-on activities. Pembelajaran seperti ini mengikuti prinsip pembelajaran konstruktivisme.

Berdasarkan jenjang dan karakteristik perkembangan intelektual siswa SMP, penyajian konsep dan keterampilan dalam pembelajaran IPA harus dimulai dari nyata (konkrit) ke abstrak. Pembelajaran dari materi mudah ke sukar, dari sederhana ke rumit dan dari dekat ke jauh. Guru harus memiliki kemampuan dalam mendesain pembelajaran IPA yang meliputi berbagai kegiatan observasi, membuat perencanaan, kemampuan melaksanakan eksperimen, melakukan evaluasi data hasil pengamatan dan sebagainya. Inilah pembelajaran IPA yang sebenarnya diharapkan di kelas.

Kondisi awal dari siswa dalam kelas VIII $F$ adalah pasif selama pembelajaran dan ada kecenderungan malas berpikir atau tidak memberdayakan kemampuan berpikir. Hal ini tak hanya terlihat melalui observasi keaktifan dikelas etapi juga pada jawaban siswa yang cenderung mengutip buku. Rendahnya argumentasi siswa ketika diskusi menjadi pendukung atas gambaran pasifnya kelas ini. Secara garis besar kemampuan analitik siswa kelas VIII F SMP Negeri 3 Jember masih relatif rendah.

Keaktifan siswa dalam pembelajaran penting sebagai bentuk nyata interaksi antara guru dengan siswa ataupun siswa dengan siswa. Aktivitas dalam pembelajaran 
menentukan hasil belajar siswa. Suasana kelas yang aktif dan kondusif dapat melibatkan kemampuan siswa berkembang semaksimal mungkin. Dalam penelitian ini aktivitas siswa yang dimaksud adalah keterlibatan siswa dalam mengikuti pembelajaran. Pembelajaran yang didominasi guru menimbulkan kebosanan bagi siswa dikarenakan aktivitas siswa terbatas pada mendengarkan dan mencatat. Rancangan atau skenario pembelajaran yang dibuat guru harusnya berorientasi pada aktivitas siswa. Kelemahan lain yang tampak pada konsisi awal kelas VIII $\mathrm{F}$ adalah kegiatan pembelajaran mayoritas pada guru. Pembelajaran cederung hanya mengasah kemampuan pengetahuan dan pemahaman siswa saja. Pengembangan kemampuan analitik siswa kurang dilatihkan oleh guru. Hal ini mengakibatkan kemampuan analitik siswa menjadi kurang terasah.

Definisi kemampuan analitik menurut Triyono (2008) adalah kemampuan analisis seseorang terhadap informasi dan dapat menarik kesimpulan dari analisis informasi yang diperoleh. Kesimpulan analisis sebuah informasi tersebut dapat digunakan siswa untuk menyelesaikan masalah dalam kehidupan sehari-hari dalam penerapannya. Kemampuan berpikir analitis merupakan kemampuan untuk membagi dan menguraikan suatu pengetahuan atau masalah menjadi bagian yang penting dan tidak penting. Kemampuan untuk mencari hubungan dari komponenkomponen pengetahuan. Kemampuan berpikir analitis terdiri atas aspek untuk memilah, mengorganisasi, dan mengatribusi (Anderson \& Krathwohl dalam Nuraini, dkk., 2016). Kemampuan analitik sangat bermanfaat dalam aspek kognitif siswa khususnya pada pengetahuan dan pemahaman (Assegaff \& Sontani, 2016).

Guru dalam mengatasi masalah ini perlu melakukan perbaikan proses dalam pembelajaran. Guru perlu strategi yang bisa diterapkan dalam meningkatkan aktivitas belajar dan kemampuan analitik siswa di kelas VIII-F. Sebuah model pembelajaran POE (Prediction, Observion, Explanation) menantang siswa untuk berfikir dan memberikan kepuasan dalam taraf tertentu apabila prediksi siswa sesuai dengan hasil pengamatan. Pengelolaan kelas yang baik akan melahirkan interaksi belajar mengajar yang baik pula (Sudjana, 2008).

Menurut Puriyandari, Saputro, \& Masykuri (2014) Secara garis besar sintaks pada model pembelajaran POE sesuai dengan namanya yaitu:1) Prediction atau melakukan prediksi yaitu siswa membuat prediksi dan memperkirakan hasil dari eksperimen yang akan dilakukan pada langkah berikutnya. Dalam membuat prediksi, siswa dibebaskan berfikir seluasluasnya sesuai dengan pengetahuannya tanpa batasan dari guru; 2) Observation atau melakukan observasi yaitu siswa mengamati atau melihat eksperimen. Bagian terpenting dalam langkah ini adalah mengkonfirmasi prediksi yang telah dibuat. Dengan melakukan percobaan langsung akan memberikan dampak khusus pada pemahaman siswa; 3) Explanation atau memberi penjelasan, siswa membandingkan hasil pengamatan dalam observasi dengan prediksi kemudian membuat penjelasan berdasarkan pengetahuan sendiri.

Berdasarkan uraian tersebut, maka telah dilakukan penelitian 
tindakan kelas oleh guru dengan judul penelitian "Meningkatkan Kemampuan Analitik dan Aktivitas Siswa SMP Melalui Penerapan Model Pembelajaran POE (Prediction, Observation, Explanation)". Tujuan penelitian ini, yaitu: 1) meningkatkan kemampuan analitik siswa kelas VIII F SMP Negeri 3 Jember melalui model POE; dan 2) meningkatkan aktivitas siswa kelas VIII F SMP Negeri 3 Jember melalui penerapan model POE.

\section{METODE PENELITIAN}

Jenis penelitian ini adalah Penelitian Tindakan Kelas (PTK). Kemmis dan McTaggart dalam Arikunto (2008) menyatakan bahwa PTK merupakan bentuk refleksi diri untuk memperbaiki praktik dalam pembelajaran. PTK dilaksanakan dalam siklus spiral yang terdiri dari empat tahapan. Penelitian ini dilaksanakan dalam dua siklus dengan setiap siklus terbagi menjadi empat tahap yaitu perencanaan, pelaksanaan, pengamatan dan refleksi.

Penelitian dilaksanakan pada semester genap tahun pelajaran 2019/2020 di SMP Negeri 3 Jember yang bertempat di jalan Jawa No 8 Kecamatan Sumbersari Kabupaten Jember. Subjek penelitian yaitu siswa kelas VIII F SMP Negeri 3 Jember sebanyak 32 siswa. Instrumen yang digunakan dalam penelitian ini berupa lembar observasi, seperangkat tes, dokumentasi. Sedangkan teknik pengumpulan data adalah teknis tes dan non tes. Teknik tes berupa tes berupa penilaian yang mengacu pada indikator kemampuan analitik sesuai dengan Tabel-1 berikut.

Tabel 1. Indikator Kemampuan Analitik

\begin{tabular}{|l|l|}
\hline \multicolumn{1}{|c|}{ Indikator } & \multicolumn{1}{c|}{ Kegiatan } \\
\hline Memberikan alasan & Siswa mengungkapkan pendapatnya \\
\hline Menganalisis pernyataan & Siswa mencoba mengamati media pembelajaran \\
\hline $\begin{array}{l}\text { Membuat dan } \\
\text { mengevaluasi kesimpulan }\end{array}$ & $\begin{array}{l}\text { Siswa membandingkan hasil prediksi awal dan hasil pengamatan } \\
\text { yang dilakukan }\end{array}$ \\
\hline Menjelaskan data & $\begin{array}{l}\text { Siswa menjelaskan data yang didapat dari mulai memprediksi } \\
\text { sampai mendapatkan hasil yang benar }\end{array}$ \\
\hline
\end{tabular}

Sedangkan teknik non tes berupa: (1) observasi atau pengamatan terhadap siswa ketika melakukan proses pembelajaran dengan menggunakan model pembelajaran POE; (2) teknik dokumentasi berupa foto saat proses pembelajaran berlangsung. Lembar observasi aktivitas siswa di kelas meliputi beberapa aspek yaitu perhatian siswa terhadap penjelasan guru, kemampuan siswa mengaitkan materi dengan kehidupan sehari-hari, kemampuan siswa merangkai alat, aktivitas siswa dalam kelompok, kemampuan siswa mengemukakan pendapat, dan kemampuan siswa menarik kesimpulan. Keaktivan siswa dapat diukur menggunakan instrumen yang menyangkut aspek tersebut. 
Teknik analisis data pada penelitian ini menggunakan analisis data kuantitatif dan kualitatif. Pengolahan data kuantitatif bertujuan untuk mengetahui seberapa besar kemampuan analitik siswa pada awal pembelajaran dan perubahan yang terjadi setelah adanya penelitian tindakan kelas, penilaian mengacu pada indikator kemampuan analitik.

Hasil kemampuan analitik siswa diinterpretasikan dengan merubah total skor kepada siswa pada interval nilai 0-100 dalam bentuk persentase. Berikut ini cara penghitungan data kuantitatif, yaitu:

Presentase $=\frac{\text { sskor subyek }}{\text { इskor maksimum }} \times 100 \%$

Dari hasil penilaian melalui persentase, peneliti dapat mengelompokkan level kemampuan analitik siswa sesuai dengan Tabel 2 berikut.

Tabel 2. Level Kemampuan Analitik

\begin{tabular}{l|c}
\hline \multicolumn{1}{c|}{ Interval Skor } & Level Kemampuan \\
\hline $25 \%-43,75 \%$ & Rendah \\
\hline $43,76 \%-62,50 \%$ & Cukup \\
\hline $62,51 \%-81,25 \%$ & Baik \\
\hline $81,26 \%-100 \%$ & Sangat Baik \\
\hline
\end{tabular}

Lembar observasi digunakan untuk memperoleh data pengelolaan model pembelajaran dan aktivitas siswa selama proses pembelajaran berlangsung. Pada metode ini, peneliti dibantu oleh teman sejawat sebagai observer. Penskoran tiap aspek lembar observasi dilakukan sesuai dengan kriteria penskoran lembar observasi. Sedangkan analisis lembar observasi menggunakan rumus sebagai berikut:

$N_{\text {observasi }}=\frac{\Sigma \text { skor perolehan }}{\Sigma \text { skor maximum }} \times 100 \%$
Penentuan kriteria nilai disesuaikan dengan rentang dalam Tabel 3.

Tabel 3. Klasifikasi presentase nilai

\begin{tabular}{l|l}
\hline Rentang Persentase & Kriteria \\
\hline $25,00 \% \leq \mathrm{N} \leq 43.75 \%$ & Tidak Baik \\
\hline $43,75 \%<\mathrm{N} \leq 62.50 \%$ & Cukup Baik \\
\hline $62,50 \%<\mathrm{N} \leq 81.25 \%$ & Baik \\
\hline $81,25 \%<\mathrm{N} \leq 100 \%$ & Sangat Baik \\
\hline
\end{tabular}

Kriteria keberhasilan pada penelitian Tindakan Kelas ini adalah 1)apabila kemampuan analitik siswa mendapatkan minimal $85 \%$ skor skala yang berada pada tingkat kemampuan sangat baik. Selain itu, indikator keberhasilan kemampuan analitik siswa tercapai jika meningkat pada tiap siklus secara klasikal; 2)aktivitas belajar siswa meningkat dengan nilai minimal dengan kriteria baik.

\section{HASIL DAN PEMBAHASAN}

Kegiatan belajar mengajar dengan menerapkan model POE pada konsep Tekanan Zat di kelas VIII F SMP Negeri 3 Jember yang dilakukan sebanyak dua siklus telah berhasil dilaksanakan. Masing-masing siklus melalui empat tahapan yaitu perencanaan, pelaksanaan tindakan, pengamatan, dan refleksi.

Pada tahap perencanaan siklus I perlu pematangan konsep dan memahami beberapa contoh penerapan model POE dalam pembelajaran. Pembuatan Rencana Pelaksanaan Pembelajaran (RPP) konsep Tekanan Zat, menyusun bahan ajar berupa lembar kerja peserta didik (LKPD), menyiapkan tes tulis kemampuan analitik, rubrik pensekoran dan lembar observasi penelitian.

Tahap kedua adalah tahap pelaksanaan, menyampaikan tujuan pembelajaran, mengenalkan topik dan 
menyampaikan materi dengan model POE kepada siswa di kelas. Pada pertemuan tersebut didapatkan data hasil kemampuan analitik siswa melalui tes tulis dan data hasil observasi kegiatan dan data berupa dokumentasi kegiatan.

Tahap observasi sebagai tahapan penelitian yang ketiga dilakukan selama pembelajaran di kelas berlangsung dalam menerapkan model POE. Hasil pengamatan menunjukkan siswa masih lemah pada indikator kemampuan analitik memprediksi. Kemampuan siswa dalam memberikan alasan mengenai percobaan konsep tekanan zat didapat skor rata-rata dari 14 siswa adalah 69 dengan persentase 69\%. Prosentase ini pada tingkatan kriteria baik. Kegiatan analisis dan pengamatan dalam percobaan Tekanan Zat skor yang diperoleh siswa sebesar 71 dengan persentase $71 \%$. Pencapaian ini pada tingkat kemampuan kriteria baik.

$$
\text { Hasil observasi penelitian }
$$

menunjukkan siswa tampak bersemangat selama pembelajaran berlangsung. Indikator menyimpulkan dan membandingkan diperoleh skor 68 dengan tingkat persentase $68 \%$. Skor ini berada pada tingkatan kriteria baik.
Indikator terakhir dalam pembelajaran yaitu menjelaskan hasil data dengan skor 82 pada persentase $82 \%$. Kriteria pada tingkatan kemampuan baik.

Tahap akhir dalam penelitian tindakan kelas yaitu tahapan refleksi kegiatan. Hasil penelitian di siklus I dinyatakan bahwa siswa dalam kelas VIII F memiliki kemampuan analitik dengan kriteria baik. Hanya saja besarnya persentase total rata-rata skor kemampuan analitik siswa kelas VIII F siklus I adalah $73 \%$. Persentase ini masih dibawah nilai yang ditetapkan dalam indikator keberhasilan penelitian yaitu minimal pencapaian total skor kemampuan analitik $85 \%$. Ketidakberhasilan meningkatkan kemampuan analitik siswa ini secara analisis karena siswa belum terbiasa menggunakan model pembelajaran POE. Siswa selama pembelajaran tampak bersemangat dan antusias menggunakan model POE karena model pembelajaran ini baru. Model pembelajaran yang melibatkan aktivitas siswa berpikir dan melakukan analisis sebuah konsep materi tekanan zat. Hasil kemampuan analitik siswa dalam siklus I dapat dilihat dalam Tabel 4.

Tabel 4. Hasil Kemampuan Analitik pada Siklus I

\begin{tabular}{l|l|c}
\hline \multicolumn{1}{c|}{ Indikator } & \multicolumn{1}{c}{ Kegiatan } & \multicolumn{1}{c}{\begin{tabular}{c}
\multicolumn{1}{c}{ Skor } \\
Presentase
\end{tabular}} \\
\hline $\begin{array}{l}\text { Memberikan } \\
\text { alasan }\end{array}$ & $\begin{array}{l}\text { Siswa mengungkapkan pendapatnya/ memprediksi Tekanan } \\
\text { Zatmelalui media yang disediakan guru }\end{array}$ & $69 \%$ \\
\hline $\begin{array}{l}\text { Menganalisis } \\
\text { pernyataan- } \\
\text { pernyataan }\end{array}$ & $\begin{array}{l}\text { Siswa mencoba mengamati media pembelajaran mengenai } \\
\text { Tekanan Zat }\end{array}$ & $71 \%$ \\
\hline $\begin{array}{l}\text { Membuat dan } \\
\text { mengevaluasi } \\
\text { kesimpulan }\end{array}$ & $\begin{array}{l}\text { Siswa membandingkan hasil prediksi awal dan hasil } \\
\text { pengamatan yang dilakukan. Siswa menyimpulkan hasil } \\
\text { pengamatan yang dilakukan }\end{array}$ & $68 \%$ \\
\hline $\begin{array}{l}\text { Menjelaskan } \\
\text { data }\end{array}$ & $\begin{array}{l}\text { Siswa menjelaskan data yang didapat dari mulai memprediksi } \\
\text { sampai mendapatkan hasil yang benar }\end{array}$ & $82 \%$ \\
\hline \multicolumn{2}{l}{ Jumlah rata-rata total skor persentase } & $\mathbf{7 3 ~ \%}$ \\
\hline
\end{tabular}


Tahap perencanaan pada siklus II merupakan kegiatan perbaikan yang disesuaikan dengan hasil refleksi dari siklus I. Penyusunan RPP, bahan ajar lembar kerja peserta didik, tes tulis kemampuan analitik,rubrik pensekoran serta penyusunan lembar observasi penelitian diperbaiki sesuai dengan hasil refleksi siklus I. Tahap selanjutnya adalah tahap pelaksanaan dan observasi yang dilakukan secara bersamaan selama pembelajaran berlangsung. Hasil observasi siklus II menunjukkan bahwa siswa memiliki keaktifan dengan kriteria yang sama baik dengan siklus I. Siswa bersemangat mengikuti pembelajaran dan terdapat interaksi yang baik antara siswa dengan guru dan interaksi antar siswa.

Hasil tes kemampuan analitik siklus II pada indikator kemampuan memberikan alasan mendapat skor 86 dengan persentase $86 \%$. Skor ini berada pada kriteria sangat baik. Indikator kedua kemampuan analitik yaitu menganalisis pernyataan- pernyataan mendapat skor 85 dengan persentase $85 \%$ kriteria sangat baik. Indikator kemampuan analitik ketiga membuat dan mengevaluasi sebuah kesimpulan mendapat skor 85 dengan persentase $85 \%$. Skor ini berada pada kriteria sangat baik. Indikator terakhir kemampuan analitik menjelaskan data mendapat skor 88 dengan persentase $88 \%$. Skor ini berada pada kriteria baik. Jumlah total rata-rata skor kemampuan analitik siswa VIII F di siklus II mencapai nilai sebesar $86 \%$.

Tahapan akhir penelitian siklus II adalah refleksi dapat dinyatakan bahwa penelitian ini berhasil mencapai tujuan. Tujuan penelitian untuk meningkatkan keaktifan siswa dengan kriteria baik telah dicapai. Tujuan untuk meningkatkan kemampuan analitik siswa tercapai di siklus II dengan persentase $86 \%$. Angka ini melampaui persentase minimal keberhasilan penelitian yaitu $85 \%$. Rincian hasil kemampuan analitik siswa kelas VIII F di siklus II dapat dilihat dalam Tabel 5 berikut.

Tabel 5. Hasil Kemampuan Analitik pada Siklus II

\begin{tabular}{l|l|c}
\hline \multicolumn{1}{c|}{ Indikator } & \multicolumn{1}{c}{ Kegiatan } & Presentase \\
\hline Memberikan alasan & Siswa mengungkapkan pendapatnya & $86 \%$ \\
\hline Menganalisis pernyataan & Siswa mencoba mengamati media pembelajaran & $85 \%$ \\
\hline $\begin{array}{l}\text { Membuat dan } \\
\text { mengevaluasi kesimpulan }\end{array}$ & $\begin{array}{l}\text { Siswa membandingkan hasil prediksi awal dan hasil } \\
\text { pengamatan yang dilakukandan menyimpulkan }\end{array}$ & $85 \%$ \\
\hline Menjelaskan data & $\begin{array}{l}\text { Siswa menjelaskan data yang didapat dari mulai } \\
\text { memprediksi sampai mendapatkan hasil yang benar }\end{array}$ & $88 \%$ \\
\hline \multicolumn{2}{l}{ Jumlah rata-rata skor persentase } & $\mathbf{8 6 \%}$ \\
\hline
\end{tabular}

\begin{tabular}{|c|c|c|c|c|c|}
\hline \multirow{5}{*}{$\begin{array}{r}100 \% \\
80 \% \\
60 \% \\
40 \% \\
20 \% \\
0 \%\end{array}$} & & & \multirow[b]{5}{*}{$\begin{array}{l}\text { Membuat,men } \\
\text { gevaluasi } \\
\text { kesimpulan }\end{array}$} & \multirow[b]{5}{*}{$\begin{array}{c}\text { Menjelaskan } \\
\text { data }\end{array}$} & \multirow[b]{5}{*}{ Rata-rata } \\
\hline & & & & & \\
\hline & & & & & \\
\hline & & & & & \\
\hline & $\begin{array}{c}\text { Memberikan } \\
\text { alasan }\end{array}$ & $\begin{array}{c}\text { Menganalisis } \\
\text { pernyataan }\end{array}$ & & & \\
\hline siklus I & $69 \%$ & $71 \%$ & $68 \%$ & $82 \%$ & $73 \%$ \\
\hline a siklus II & $86 \%$ & $85 \%$ & $85 \%$ & $88 \%$ & $86 \%$ \\
\hline
\end{tabular}


Gambar 1. Diagram-1 Perbandingan kemampuan analitik siswa di siklus I dan II

Hasil yang ditunjukkan pada Gambar 1 menunjukkan keberhasilan dalam penelitian karena mengalami peningkatan kemampuan analitik dari $73 \%$ di siklus I menjadi $86 \%$ pada siklus II. Rata-rata kemampuan analitik siklus II berada pada tingkat kemampuan dengan kriteria sangat baik.

Tingkat kriteria keberhasilan pada penelitian tindakan kelas ini siswa mendapatkan minimal skor $85 \%$. Berdasarkan hasil analisis data aktivitas siswa diperoleh hasil pencapaian tiap aspek dalam lembar observasi seperti pada Tabel 6 dan Tabel 7.

Tabel 6. Aktivitas Siswa Melalui Lembar Observasi Siklus I dan II

\begin{tabular}{c|l|c|c}
\hline No & \multicolumn{1}{|c|}{ Indikator Aktivitas } & Siklus I & Siklus II \\
\hline 1 & Perhatian siswa terhadap penjelasan guru & $72,7 \%$ & $82,8 \%$ \\
\hline 2 & Kemampuan mengaitkan materi dengan kehidupan sehari-hari & $68,8 \%$ & $77,3 \%$ \\
\hline 3 & Kemampuan siswa merangkai alat & $75,8 \%$ & $80,5 \%$ \\
\hline 4 & Aktivitas siswa dalam kelompok & $73,4 \%$ & $78,9 \%$ \\
\hline 5 & Kemampuan siswa mengemukakan pendapat & $71,1 \%$ & $78,1 \%$ \\
\hline 6 & Kemampuan siswa menarik kesimpulan & $68,8 \%$ & $76,6 \%$ \\
\hline \multicolumn{2}{r}{$\quad$ Rata-Rata } & $\mathbf{7 4 , 5 \%}$ & $\mathbf{8 2 , 4 \%}$ \\
\hline \multicolumn{2}{r}{ Kategori } & Baik & Sangat Baik \\
\hline
\end{tabular}

Tabel 7. Pencapaian Aktivitas Siswa Siklus I dan II

\begin{tabular}{l|c|c|c|c}
\hline \multirow{2}{*}{ Kriteria Aktivitas } & \multicolumn{2}{|c}{ Siklus I } & \multicolumn{2}{c}{ Siklus I } \\
\cline { 2 - 5 } & Siswa & Persentase & Ssiswa & Persentase \\
\hline Tidak Baik & 0 & $0,0 \%$ & 0 & $0,0 \%$ \\
\hline Cukup Baik & 4 & $12,5 \%$ & 0 & $0,0 \%$ \\
\hline Baik & 22 & $68,8 \%$ & 29 & $40,6 \%$ \\
\hline Sangat Baik & 6 & $18,8 \%$ & 9 & $59,4 \%$ \\
\hline
\end{tabular}

Keseluruhan hasil menunjukkan siswa VIIIF telah aktif. Pernyataan ini dibuktikan dengan pencapaian klasifikasi nilai $\mathrm{N} \leq 81,25 \%$. Keberhasilan penelitian mencapai nilai minimal kriteria aktivitas siswa baik. Pencapaian aktivitas dipengaruhi berbagai faktor antara lain ketertarikan siswa terhadap pembelajaran, motivasi dan rasa ingin tahu siswa. Pembelajaran yang efektif adalah pembelajaran yang memberikan banyak kesempatan pada siswa melakukan aktivitas secara aktif.
Hasil ini menunjukkan penerapan pembelajaran POE efisien untuk mengaktifkan siswa selama pembelajaran konsep tekanan zat. Ketercapaian kinerja guru dalam hal ini adalah keterlaksanaan tahapan pembelajaran POE sesuai RPP yang disusun dengan capaian minimal baik. Hasil analisis diketahui kriteria kinerja guru selama pembelajaran di kelas adalah sangat baik dapat dilihat pada Tabel 8 berikut. 
Tabel 8. Hasil Penilaian Kinerja Guru

\begin{tabular}{|c|c|c|c|}
\hline \multirow{2}{*}{ No } & \multirow{2}{*}{ Aspek Pembelajaran } & \multicolumn{2}{|c|}{ Skor Pelaksanaan } \\
\hline & & Observer 1 & Observer 2 \\
\hline 1 & Kegiatan Pembuka & $83,3 \%$ & $91,7 \%$ \\
\hline 2 & Kegiatan Inti & $80,6 \%$ & $80,6 \%$ \\
\hline 3 & Kegiatan Penutup & $75,0 \%$ & $87,5 \%$ \\
\hline & Rata-rata & 79,6 \% (Baik) & $86,6 \%$ (Sangat Baik) \\
\hline
\end{tabular}

Berdasarkan Tabel 8 diketahui bahwa persentase kinerja guru 83,1 memiliki kriteria Sangat Baik. Kriteria kinerja guru ditentukan berdasarkan klasifikasi persentase jumlah skornya. Hasil wawancara dengan siswa menunjukkan bahwa model POE mampu melatih siswa untuk memecahkan masalah dengan cara menganalisis suatu masalah sehingga mampu meningkatkan kemampuan berpikir analitis siswa. Selain itu, siswa juga merasa lebih aktif dalam proses pembelajaran dengan adanya penyelidikan mandiri, diskusi dan kesempatan siswa untuk saling bertukar pendapat dalam menyelesaikan masalah. Kendala yang dihadapi dalam penelitian adalah ketika observer menilai aktivitas siswa, dimana aktivitas ini dinilai secara individu. Kendala ini dikarenakan ketidaktahuan subjek dengan nama subjek yang akan dinilai.

\section{KESIMPULAN}

Disimpulkan dari keberhasilan penelitian ini bahwa terjadi peningkatan kemampuan analitik siswa dari siklus I ke siklus II. Penerapan model POE meningkatkan aktivitas siswa dalam belajar. Penerapan Model POE pada mampu menciptakan situasi pembelajaran lebih variatif dan kondusif sehingga meningkatkan kemampuan berpikir analitik siswa dan meningkatkan interaksi positif antar siswa dan antara guru dengan siswa. Pembelajaran model POE dapat meningkatkan keingintahuan siswa dan kerja secara berkelompok dapat menimbulkan interaksi anggota, sehingga aktivitas siswa meningkat.

\section{DAFTAR PUSTAKA}

Arikunto, S. (2008). Prosedur Penelitian. Jakarta: Rineka Cipta.

Assegaff, A., \& Sontani U. T. (2016). Upaya Meningkatkan Kemampuan Berfikir Analitis Melalui Model Problem Based Learning (PBL). Jurnal Pendidikan Manajemen Perkantoran. 40-51.

Sudjana, N. 2008. Pendekatan dalam Pembelajaran. Jakarta: Sinar Baru Algesindo

Triyono, M. B. (2008). Pengaruh Strategi Pembelajaran Dan Kemampuan Analitik Terhadap Keterampilan Pneumatik Mahasiswa Teknik Mesin UNY. Jurnal Penelitian Dan Evaluasi Pendidikan. 1-19

Nesli,K., Atma, Y. dan Alipasa, A. (2012). International Journal of Science and Mathematics Education. 11: 555-574

Nuraini, A., Dwiastuti, S., Fatmawati, U.(2016). Kemampuan Berpikir Analitis Siswa Melalui Penerapan Model Pembelajaran 
Inkuiri Terbimbing. Unnes Journal of Biology Education. Diakses Online: http://journal.unnes.ac.id/sju/ind ex.php/ujbe

Puriyandari, D., Saputro, A. N. C., \& Masykuri, M. (2014). Penerapan Model POE dilengkapi Lembar Kerja Siswa Untuk Meningkatkan Sikap Ilmiah Dan Prestasi Belajar Materi Kelarutan Dan Hasil Kali Kelarutan Siswa Kelas XI IPA Semester Genap SMA Negeri 1 Ngemplak Tahun Pelajaran 2012/2013. Jurnal Pendidikan Kimia (JPK). 3(1). 24-30.
Restami, M. P., Suma, K., \& Pujani, M. (2013). Pengaruh Model Pembelajaran Poe (PredictObserveExplaint) Terhadap Pemahaman Konsep Fisika Dan Sikap Ilmiah Ditinjau Dari Gaya Belajar Siswa. EJournal Program Pascasarjana Universitas Pendidikan Ganesha. 3. 1-11. 